\title{
Tyranny of the Majority: Hegel on the Paradox of Democracy
}

Jeffry V. Ocay

\begin{abstract}
At the core of the principle of democracy is the claim that all individuals, or as many as possible, should decide for themselves and that they must be included in collective governance of the community in which the majority rules. However, drawing upon Hegel's theory of the state, I will show in this paper that in a democracy, the emphasis on individual rights, at the expense of developing the notion of universal good, is not only problematic, but dangerous because in the absence of rational authority of the state, people rely mainly on public opinion for guidance, which results in what Hegel may call the tyranny of the majority. As a consequence, democracy, which purports itself to be the champion of freedom, tends to be exclusivist and totalitarian as dissenting ideas are silenced by the "ruling majority" in actual democratic processes. In fact, the notion of "legitimacy" (i.e., legitimated by the majority) conduces to the assault on the inner will to resist rendering individuals in a democracy as "conformists." The paper concludes that, for Hegel, freedom can be realized not through democracy as espoused by the liberal theorists, but through his theory of the state-the state being not only a guarantor of basic rights and liberties, but as a dimension of freedom which commits itself to a substantive vision of the universal good as the paramount object of human aspiration.
\end{abstract}

Keywords: Hegel, freedom, democracy, ethical life

\section{Introduction}

7 he liberal theorists from Hobbes to Locke, down to Kant, Fichte, and, just recently, Rawls viewed democracy as the most fertile ground for the realization of freedom. As is well-known, the liberal theorists argued that freedom is given and that it finds expression in a democratic society. Thus, for the liberal theorists, democracy safeguards individual civil liberties through the constitution which is above the state. As we can see, this eventually makes the court the highest authority in a liberal society.

(c) 2020 Jeffry V. Ocay

https://www.kritike.org/journal/issue 27/ocay december2020.pdf

ISSN 1908-7330 
However, this paper shows that the contention of the liberal theorists is insufficient to account for real freedom. ${ }^{1}$ I will show that instead, democracy has resulted in what Hegel may call the tyranny of the majority. I will also show that freedom is a product of a long and arduous historical process and that it finds expression not in democracy but in Hegel's theory of the statethe state being not only a guarantor of basic rights and liberties, but as a dimension of freedom which commits itself to a substantive vision of the universal good as the paramount object of human aspiration.

In what follows, I will briefly sketch Hegel's concept of freedom through a critical engagement with his seminal work, Philosophy of Right and then, I will present the reason why Hegel thought that liberal democracy is unsuccessful in accounting for the possibility of true freedom. In doing so, however, I will try as much as possible to avoid running the risk of being apologetic toward Hegel. Following Axel Honneth, I believe that to simply rehash the intention and argument of Hegel's Philosophy of Right would be anachronistic given that the social realities and style of philosophizing during Hegel's time had undergone significant changes. ${ }^{2}$ For example, in the face of rigid bureaucracy, which characterizes modern societies, it would be politically naïve, if not ridiculous, to push for a return to constitutional monarchies of the early nineteenth century. Furthermore, as Honneth argues, we can no longer share Hegel's optimism that modern societies follow a continuous path of rational development since the historical development of modern societies, especially those that we witnessed during the second half of the twentieth century, had undergone significant regressions. ${ }^{3}$ And lastly,

\footnotetext{
${ }^{1}$ Of course, there is no absolute definition of democracy. The term democracy is elastic and continues to evolve with time. The different conceptions or types of democracy also add to our difficulty in defining the term. For example, in recent years, Jürgen Habermas introduces three different normative grounds for democracy, namely, liberal, republican, and deliberative. See Odin Lysaker, "Institutional Agonism: Axel Honneth's Radical Democracy," Critical Horizons, 18:1, (February 2017), 33-51. Axel Honneth, another German philosopher of the Frankfurt School tradition, also offers what some scholars call a "radical conception of democracy." In his famous Freedom's Right, Honneth provides an interpretation of Hegel's Philosophy of Right that presents the ethical life as precisely the realization of the democratic ideal. See Axel Honneth, Freedom's Right: The Social Foundations of Democratic Life, (New York: Columbia University Press, 2014). However, its etymological definition and what it implies remain constant, that is, democracy comes from the two Greek words demos, which means "whole citizen living within a particular city-state, and kratos, which means "power or rule." Hence, etymologically speaking, democracy means "rule by the people," which necessarily implies the championing of the development and well-being of the citizens, including the protection of their rights and liberties. As I see it, Hegel is criticizing this entire conception of liberal democracy and not just a specific version of democracy which has the tendency to develop a certain form of individualistic authoritarianism.

${ }^{2}$ Axel Honneth, Freedom's Right: The Social Foundations of Democratic Life, trans. Joseph Ganahl (New York: Columbia University Press, 2014), 2.

${ }^{3}$ Ibid., $2-3$.
}

(c) 2020 Jeffry V. Ocay

https://www.kritike.org/journal/issue 27/ocay december2020.pdf

ISSN 1908-7330 


\section{HEGEL ON THE PARADOX OF DEMOCRACY}

the theoretical premises of philosophical discussion, according to Honneth, have also undergone a major shift since Hegel's time. In fact, Honneth stresses that the individuals in a materially enlightened era could hardly "hold onto the idealistic monism in which Hegel anchored his dialectical concept of Spirit." 4 Given the following caveat, my brief presentation of Hegel's concept of freedom and his critique of democracy would be purely expository.

\section{Hegel's Take on Democracy: A Brief Sketch}

Perhaps the best way to articulate Hegel's opposition to democracy is to start our discussion with the nature and dynamics of democracy with emphasis on its internal contradictions. As is well-known, at the core of the principle of democracy is the claim that all individuals, or as many as possible, should decide for themselves and that they must be included in collective governance of the community in which the majority rules. ${ }^{5}$ This principle presumes that political power comes from the people and that government is legitimate only when the people consent. Hence, the proponents of modern democracy believed that the creation of governments, as well as the organization of society, was made possible through a social contract. With this came the idea that people are essentially equal under natural law and that political power was derived from the people. What this implies is that for the social contract theorists, every individual possesses certain natural or inalienable rights and, therefore, is essentially free. For this reason, the social contract theorists believed that "individuals are not indebted to government or political society for their rights; rather government has its origins in the rational desires of individuals to protect their preexisting rights as human beings." 6 The conservative Hobbes, for example, argued that a Leviathan must be instituted to safeguard the individuals' rights and interests. Similarly, the liberal Locke, who was so particular about private property, argued that society exists for the protection of the rights of individuals (especially the right to private property).

While it can be said that democracy aims for the maximization of freedom or the expansion of autonomy, its emphasis on individual rights has rendered "human beings cut off from the external world of social settings and

\footnotetext{
${ }^{4}$ Ibid., 3.

${ }^{5}$ For more discussion on Hegel's take on democracy, see Lucio Cortella, The Ethics of Democracy: A Contemporary Reading of Hegel's Philosophy of Right, trans. by Giacomo Donis (New York: SUNY Press, 2015) and Mark Tunick, "Hegel's claim about Democracy and his Philosophy of History," in Hegel and History (New York: SUNY Press, 2009).

${ }^{6}$ Steven B. Smith, Hegel's Critique of Liberalism: Rights in Context, (Chicago and London: The University of Chicago Press, 1989), 61.

(c) 2020 Jeffry V. Ocay

https://www.kritike.org/journal/issue 27/ocay december2020.pdf

ISSN 1908-7330

(c) BY-NC-ND
} 
institutions." 7 With the absence of such social settings and institutions, which, as I will show later, is the ground for the actualization of true freedom and its eventual expansion, people rely mainly on public opinion for guidance that results in, again, what Hegel may call the tyranny of the majority. Democracy, therefore, as Hegel sees it, tends to be exclusivist as dissenting opinions are silenced in actual democratic processes. ${ }^{8}$ In fact, the notion of "legitimacy" (i.e., legitimated by the majority) conduces to the assault on the inner will to resist, rendering individuals in democratic societies as "conformists." W. G. Stratton rightly observes that the "democratic model allows for an ongoing shaping of law and social structure according to the dictate of popular sentiment." ${ }^{9}$ In this light, it is therefore not difficult for us to see why Hegel argues that democracy leads to tyranny of the majority, which may only block the actualization of true freedom. It is precisely in this respect that democracy, viewed from a Hegelian lens, is paradoxical. But what is true freedom for Hegel and how can it be actualized?

\section{Hegel's Notion of the State and the Actualization of Freedom}

Although individual freedom is crucial to the realization of social justice, for Hegel, it remains insufficient to account for true freedom. According to Honneth, Hegel argues that individuals need to elevate personal freedom to the level of the social, that is, individuals must also find their freedom or "self-actualization" through shared projects. ${ }^{10}$ Here, Hegel's notion of mutual recognition takes center stage. According to Honneth, mutual recognition is the key to understanding Hegel's concept of freedom. It is worthwhile to rehash at this point Hegel's concept of mutual recognition that he fully articulated in his seminal work, Phenomenology of Spirit.

In the process of the actualization of freedom, Hegel says that selfconsciousness begins with "desire," which is twofold, namely: the desire for real objects; and self-consciousness's desire to realize itself through the realization of desire. ${ }^{11}$ First of all, desire is to be understood in the

\footnotetext{
${ }^{7}$ Honneth, Freedom's Right, 44.

${ }^{8}$ In fact, Slavoj Žižek, appropriates Hegel's dialectic in his attack against liberal democracy. Following Hegel, Žižek argues that "exclusivity" is internal to liberal democracy. See Slavoj Žižek, "The Violence of Liberal Democracy," Assemblage, 20 (April 1993), 92. See also Slavoj Žižek, Less Than Nothing: Hegel and the Shadow of Dialectical Materialism (London: Verso, 2012).

${ }^{9}$ W. G. Stratton, "The Problem of Democracy in Hegel's Philosophy of Law," Archives for Philosophy of Law and Social Philosophy, 74:1 (1998), 40.

10 Axel Honneth, The Pathologies of Individual Freedom: Hegel's Social Theory, trans. Ladislaus Lob, (Princeton and Oxford: Princeton University Press, 2010).

${ }^{11}$ It can be loosely understood as the desire of the individual to be free. Thus, as we can see in Hegel's discussion of the master-slave dialectic, the slave is said to have the desire to be free from the master and enjoy the fruit of his own labor. Yet, because he is attached to thinghood, to things that the slave also desires, the master continues to dominate the thing by 
psychological sense, for example, as a craving for something that satisfies physiological needs. But this satisfaction of need also entails the attempt of self-consciousness to assert itself as self-consciousness. Thus, desire, for Hegel, means the original attitude of the "I" as self-consciousness toward the world. In other words, desire is the necessary tendency of the acting " $\mathrm{I}$ " to make itself actual, that is, as free being; it is indeed the necessary self-showing of the acting "I." The satisfaction of this desire is precisely the fulfillment of the actual Being of the "I." However, the satisfaction of desire cannot provide the attestation of the free status that it is seeking. This is where recognition is needed. For Hegel, self-consciousness exists in itself and for itself only by being recognized by the other conscious self. ${ }^{12}$ According to Herbert Marcuse, this process is a "we-like" process of Life. Here, there is an essential reciprocal dependence; in other words, there is an essential demand for reciprocal recognition. ${ }^{13}$ As Robert $R$. Williams has shown in detail in his major studies on recognition, the "We" is a universal consciousness which results from mutual recognition, that is, when the " $\mathrm{I}$ " is recognized by the other "I." 14 Translated into concrete social relations, mutual recognition for Hegel "refers to the reciprocal experience of seeing ourselves confirmed in the desires and aims of the other, because the other's existence represents a condition for fulfilling our own desires and aims." ${ }^{15}$ As we can see, it is through mutual recognition, therefore, that individual freedom expands into intersubjective freedom, and expands, once again, into a "social" concept of freedom.

It is important to remember, however, that Hegel's notion of mutual recognition does not simply mean that individuals recognize themselves as free beings. Aside from the fact that before the "we" can emerge as a full

\footnotetext{
dominating the slave. See Donald Phillip Verene, Hegel's Absolute: An Introduction to Reading the Phenomenology of Spirit, (New York: State University of New York Press, 2007), 58-59. See also Jeffry Ocay, "Hegel Reframed: Marcuse on the Dialectic of Social Transformation," in Philosophia: International Journal of Philosophy, 16:1, (January 2015), 102-109; Jeffry Ocay, "Heidegger, Hegel, Marx: Marcuse and the Theory of Historicity," Kritike: An Online Journal of Philosophy, 2:2 (December 2008), 46-64; Jeffry Ocay, "Ethics of Refusal: Globalization and the Penan People's Struggle for Recognition," in Budhi: A Journal of Ideas and Culture, 19:2\&3, (2015), 169-195; and Jeffry Ocay, "Eroticizing Marx, Revolutionizing Freud: Marcuse's Psychoanalytic Turn", in KRITIKE: An Online Journal of Philosophy, 3:1, (June 2009), 10-23.

${ }^{12}$ Ibid., 229.

${ }^{13}$ Herbert Marcuse, Hegel's Ontology and the Theory of Historicity, translated by Seyla Benhabib, (Massachusetts: The MIT Press, 1987), 251.

${ }^{14}$ Robert R. Williams, Translator's Introduction to Georg Wilhelm Friedrich Hegel, Lectures on the Philosophy of Spirit, 1827-8, trans. by Robert R. Williams (New York: Oxford University Press, 2007), 19. See also Robert R. Williams, Recognition: Fichte and Hegel on the Other (Albany: SUNY Press, 1992).

${ }^{15}$ Honneth, Freedom's Right, 45. See also Jean-Philippe Deranty, Beyond Communication: A Critical Study of Axel Honneth's Social Philosophy (Leiden: E.J. Brill, 2009), and Jean-Philippe Deranty and Emmanuel Renault, "Politicizing Honneth's Ethics of Recognition," Thesis Eleven, 88:1 (February 2007), 92-111.
}

(c) 2020 Jeffry V. Ocay

https://www.kritike.org/journal/issue 27/ocay december2020.pdf

ISSN 1908-7330

(cc) BY-NC-ND 
community of recognition, a specific dialectic must be gone through which involves the famous concept of the struggle for recognition. For Hegel, mutual recognition requires a specific social and cultural context upon which such recognition is grounded. In other words, mutual recognition needs to be mediated by institutions and social practices, which Hegel calls "institutions of ethical life" or Sittlichkeit. Hegel claims that it is only through the institutions of ethical life, in which the individuals participate, can they recognize each other as free beings. ${ }^{16}$ This is because the primary role of the institutions of ethical life is to preserve and enhance the individuals' right to mutual recognition.

The ethical life for Hegel, therefore, is the consummate actualization of freedom. As Hegel writes in the concluding sentence of Paragraph 142 of the Philosophy of Right: "The ethical system is thus the conception of freedom developed into a present world, and also into the nature of selfconsciousness." ${ }^{17}$ And in Paragraph 143, Hegel further writes:

The conception of the universal will, when united with the realization of the will, or the particular will, is knowing. Hence arises the consciousness of the distinction between these two phases of the idea. But the consciousness is now present in such a way that each phase is separately the totality of the idea, and has the idea as its content and foundation. ${ }^{18}$

What this passage amounts to is that Hegel's notion of the ethical life as the consummate actualization of freedom is the reconciliation of subjective will and universal will. Here, the universal will, which Hegel understands as custom, does not appear as external to the individual will, but becomes a second nature, which takes the place of the original and merely natural will. ${ }^{19}$ And for Hegel, once the universal will has taken the place of the original and merely natural will, it has become "the very soul, meaning, and reality of one's life." ${ }^{20}$ Put differently, in the ethical life, the individual consciously obeys the laws of the society (or, in Talcott Parson's words, internalize the customs of the society) because she is convinced that such laws are

${ }^{16}$ See Alan Patten, Hegel's Idea of Freedom (Oxford: Oxford University Press, 2005), 125130. See also Gavin Rae, "Realizing Freedom: Hegel and Ethical Life," in Realizing Freedom: Hegel, Sartre, and the Alienation of Human Being (London: Palgrave Macmillan, 2011), 183-230.

${ }^{17}$ G. W. F. Hegel, Philosophy of Right, trans. by S. W. Dyde (Mineola, New York: Dover Publications, 2005), 76. The text will hereafter be cited by the page number. References to the paragraph number will be indicated in the body of the text.

18 Ibid. Italics mine.

${ }^{19}$ Ibid., 80.

${ }^{20}$ Ibid.

(c) 2020 Jeffry V. Ocay

https://www.kritike.org/journal/issue 27/ocay december2020.pdf

ISSN 1908-7330 
expressions of the universal will. The conformity of the particular will with the universal will, therefore, is what Hegel meant by true freedom, one that is ruled out in liberalism's individualistic conception of freedom. And it is interesting to note that Hegel calls the reconciliation of particular will and universal will "Spirit." As Hegel writes in Paragraph 151 of the Philosophy of Right, the ethical life in the form of custom "is the living spirit actualized as a world; by this actualization does the substance of spirit exist as spirit." 21 This contention provides us with the key to unlock one of the mysteries of Hegel's monumental work, Phenomenology of Spirit: that the development of Geist (Spirit) is nothing but the development of freedom actualized in the state.

\section{Freedom and the Three Moments of the Ethical Life}

Now, if we recall, Hegel says that the ethical life, as the reconciliation of the universal will and particular will, is the idea of freedom developed into the existing world and nature of self-consciousness. This means for Hegel that the ethical life is a process of development. In Paragraph 157 of the Philosophy of Right, Hegel writes: "The conception of this idea (ethical life) exists only as spirit, as active self-knowledge and reality, since it objectifies itself by passing through the form of its elements." 22 Hegel now describes the three moments that the ethical life passes through, namely: the family, civil society, and the state.

The family, for Hegel, represents ethical life in its simplest form because the unity of the family is an immediate one based on the feeling of love. In the family, members do not relate to each other as independent but as parts of a larger whole to which they immediately identify. In Robert Pippin's interpretation of Hegel's concept of the family as the first phase of the ethical life, the family is viewed as an ethically binding institution not because it is primarily a natural institution-that is, as the basic unit of society-but because we see in the family an active recognition of mutual dependencies that is a necessary requirement for the realization independence. ${ }^{23}$ However, the family also exists in a larger context where members are not bound together by the natural feeling of love. This larger context for Hegel is the realm of civil society-the sphere of economic or market relations. Although we could hardly consider the economic system today as a realm of social freedom, given the individualistic nature of the profit-seeking capitalist system, Hegel thought that individuals in the sphere

\footnotetext{
${ }^{21} \mathrm{Ibid}$. See also Paul Franco, Hegel's Philosophy of Freedom (New Haven and London: Yale University Press, 1999), 229.

${ }^{22}$ Hegel, Philosophy of Right, 82. Insertion mine.

${ }^{23}$ Robert B. Pippin, "What is the Question for which Hegel's Theory of Recognition is the Answer?," European Journal of Philosophy, 8:2 (2000), 166.

(c) 2020 Jeffry V. Ocay

https://www.kritike.org/journal/issue 27/ocay december2020.pdf

ISSN 1908-7330
}

(c) BY-NC-ND 
of market relations, of course during his time, are implicitly governed by the universal which invisibly led to serving each other's interest. As Hegel writes in Paragraph 183 of the Philosophy of Right:

The self-seeking end is conditioned in its realization by the universal. Hence is formed a system of mutual dependence, a system which interweaves the subsistence, happiness, and rights of the individuals with the subsistence, happiness, and rights of all." 24

Just as in the family, Hegel argues that the civil society as the second phase of the ethical life is, therefore, a realm of social freedom because we also see in it a kind of mutual recognition that individuals need for them to become truly free. But Hegel argues that although the civil society seems to have everything it needs for it to become complete, such as a justice system "to regulate the interactions between individuals as they pursue their economic interests, a police to maintain public order, a public authority to regulate the market and provide for the poor, and a corporations to lift individuals out of their narrow interests and lead them to identify with a more universal purpose," 25 the type of freedom it harbors remains subjective. It is for this reason that Hegel moves on to the state in order to bring into the picture the actualization of true freedom, that is, as already mentioned, the reconciliation of the universal will and the particular will.

In Paragraph 257 of the Philosophy of Right, Hegel defines the state as the actuality of the ethical spirit. ${ }^{26} \mathrm{He}$ goes on to say that "it is the will which manifests itself, makes itself clear and visible, substantiates itself. It is the will which thinks and knows itself, and carries out what it knows, and in so far as it knows." 27 According to Paul Franco, what this typically abstract phrase indicates is the essential relationship between state and freedom; the former being the actuality of the latter. ${ }^{28}$ In other words, for Hegel, the state is the concrete embodiment of true freedom. But freedom here, Franco notes, should not be understood as the particular or arbitrary will of the individual, but as the individual's substantial or rational will. What this means is that true freedom for Hegel is a kind of freedom that one enjoys in being with oneself in another, which consists in the unity of subjective and objective

${ }^{24}$ Hegel, Philosophy of Right, 97. See also Timothy C. Luther, Hegel's Critique of Modernity: Reconciling Freedom and Community, (United Kingdom: Lexington Books, 2009), 156.

${ }^{25}$ Franco, Hegel's Philosophy of Freedom, 280. See also Kenneth Kierans, “The Concept of Ethical Life in Hegel's Philosophy of Right," History of Political Thought, 12:3 (Autumn 1992), 417435 and Allen W. Wood, Hegel's Ethical Thought, (New York: Cambridge University Press, 1990).

${ }^{26}$ Hegel, Philosophy of Right, 132.

27 Ibid.

${ }^{28}$ Franco, Hegel's Philosophy of Freedom, 283.

(c) 2020 Jeffry V. Ocay https://www.kritike.org/journal/issue 27/ocay december2020.pdf ISSN 1908-7330 


\section{HEGEL ON THE PARADOX OF DEMOCRACY}

freedom. On the one hand, Hegel says that an individual is subjectively free if she reflects on her actions rather than blindly acting on the authority of public opinion. On the other, Hegel says that an individual is objectively or substantially free if her actions accord with reason, that is, if she acts in accordance with the tasks and functions (e.g., voting during elections or paying taxes) that are asked of her as a good citizen of the state. With this, we can say that being able to decide for oneself as a result of reflection is not yet true freedom for Hegel as "rational self-determination." Subjective freedom needs to pass over into objectivity, into an objective set of principles of action that individuals find themselves committed to. According to Honneth's interpretation of Hegel's concept of freedom, "a subject is only 'free' if it encounters another subject, within the framework of institutional practices, to whom it is joined in a relationship of mutual recognition." 29 This is exactly what Hegel meant by the reconciliation of the particular or individual will and the universal will. For Hegel, therefore, the state as the actuality of the ethical spirit, or the actuality of concrete or true freedom, is not only a restraint on freedom, but "the necessary context within which our individual powers and capacities can grow and develop." 30

Now, it is important to remember that in Hegel's concept of the ethical life, the individual's obedience to laws is not a blind and unconditional obedience. The individual obeys the laws because she knows that the laws are just and, hence, rational. Thus, true freedom for Hegel also implies possessing personal knowledge of reality, for example, knowing what is right and wrong. Allan Patten says that individuals do not just believe in ethical principles simply because they are laid down by external laws and precepts of authority, but individuals should have assent, disposition, conscience, and full awareness of such principles. ${ }^{31}$ In fact, according to Honneth, "Hegel did not merely wish to affirm and reinforce current practices and institutions, but also to correct and transform them." 32 Here, we have an awareness of the rationality of the laws because we obey on the basis of our own insight and reason, and not on the authority of public opinion and unexamined will. This is now the problem with which I would like to close this paper.

\footnotetext{
${ }^{29}$ Honneth, Freedom's Right, 45.

${ }^{30}$ Smith, Hegel's Critique of Liberalism, xi.

${ }^{31}$ Patten, Hegel's Idea of Freedom, 66.

32 Honneth, Freedom's Right, 8. Thus, Hegel's famous line "What is rational is real; and what is real is rational" does not mean that we are always in the midst of the "best of all possible worlds," that what exists is always actual and rational. Since actuality or reality for Hegel is always the unity of the universal and particular, then it (actuality) remains to be realized. It could be a mere potentiality that needs to be realized, to use Aristotelian terminology. In fact, for Hegel, a bad state is not a genuine reality. It merely exists. See Hegel, Philosophy of Right, 152-153. See also Trent Schroyer, The Critique of Domination: The Origins and Development of Critical Theory (Boston: Beacon Press, 1973), 55.
}

(c) 2020 Jeffry V. Ocay

https://www.kritike.org/journal/issue 27/ocay december2020.pdf

ISSN 1908-7330

(cc) BY-NC-ND 


\section{The Paradox of Democracy}

First of all, Hegel's misgiving about democracy stems from his conception of the ethical life. To reiterate, in the Hegelian conception of the state as the actuality of freedom, of the ethical spirit, we see in it a universal interest that does not sacrifice individual rights and liberties. We see in Hegel's conception of the state the actualization of Plato's notion of the Good. As already mentioned, democracy has overemphasized individual rights and liberties at the expense of developing the notion of public good. Hence, in this model of government, the state is seen simply as the guarantor of life, property, and liberty. In other words, the state in a democracy is not an "end in itself and for itself," but simply as a means for the promotion of individual interests. For this reason, democracy, as Hegel would have us believe, becomes a fertile ground for the expansion and maximization not of freedom, but of greed. With this idea in mind, it is therefore not difficult for us to see why liberal democracy goes hand in hand with capitalism.

A second reason why Hegel sees democracy as paradoxical is that "in a democracy, people are both judges and parties in the administration of law, and this poses the greatest danger to the rights of individuals and the rule of law." 33 Because the key intuition in democracy is the idea that the people are the basis of political legitimacy, and individual right is the supreme value, this means that democracy abandons the rational authority of the state in favor of public of opinion. As a consequence, democracy, which purports itself to be the champion of freedom, tends to be exclusivist and totalitarian as dissenting ideas are silenced by the "ruling majority" in actual democratic processes. In fact, the notion of "legitimacy" (i.e., legitimated by the majority) conduces to the assault on the inner will to resist, which renders individuals in a democracy as "conformists." As the famous American thinker Allan Bloom corroborates:

The most successful tyranny is not the one that uses force to assure uniformity but the one that removes the awareness of other possibilities, that makes it seem inconceivable that other ways are viable, that removes the sense that there is an outside. It is not feelings or commitments that will render a man free, but thoughts, reasoned thoughts. Feelings are largely formed and informed by convention. Real differences come from difference in thought and fundamental principle. Much

33 See Franco, Hegel's Philosophy of Freedom, 27.

(c) 2020 Jeffry V. Ocay

https://www.kritike.org/journal/issue 27/ocay december2020.pdf

ISSN 1908-7330

(cc) BY-NC-ND 
in democracy conduces to the assault on awareness of difference. ${ }^{34}$

Thus, as I noted previously, democracy's emphasis on individual rights at the expense of developing the notion of universal good is dangerous because in the absence of the rational authority of the state, people will rely mainly on public opinion for guidance. As I see it, it would seem that Hegel is making the claim that it is indeed a tyranny of the majority: a situation that is characterized primarily by the failure of democratic societies to promote the realization of true freedom. In a footnote to Paragraph 317 of the Philosophy of Right, Hegel quoted Goethe saying: "Zuschlagen kann die Masse, Da ist sie respektabel; Urtheilen gelingt ihr miserabel." 35 To reiterate, democracy for Hegel is therefore paradoxical because, as we can see in the foregoing discussion, it is incapable of manifesting the concretion of true freedom.

At this point, I think it helps if we rehash the key intuition of Hegel's theory of the state to offer some alternative to the tyranny of the majority. For Hegel, the antidote to the tyranny of the majority is the rational authority of the state. Thus, in Paragraph 258 of the Philosophy of Right, Hegel argues that the highest duty of the individual is to be a member of the state. It might be worth quoting some of the longer extracts of the Note to this paragraph:

Were the state to be considered as exchangeable with the civic society, and were its decisive features to be regarded as the security and protection of property and personal freedom, the interest of the individual as such would be the ultimate purpose of social union. It would then be at one's opinion to be a member of the state. But the state has a totally different relation to the individual. It is the objective spirit, and he has his truth, real existence, and ethical status only in being a member of it. Union, as such, is in itself the true content and end, since the individual is intended to lead a universal life. ${ }^{36}$

For Hegel then, freedom can be realized not through democracy as espoused by the liberal theorists, but through his theory of the state-the state being not only a guarantor of basic rights and liberties, but as a dimension of freedom which commits itself to a substantive vision of the universal good as

\footnotetext{
${ }^{34}$ Allan Bloom, The Closing of the American Mind, (New York: Simon \& Schuster, 1987), 249.

35 "The masses are respectable hands at fighting, but miserable hands at judging." Goethe, "Sprichtwörtlich" (1825), as quoted in Hegel, Philosophy of Right, 188.

${ }^{36} \mathrm{Hegel}$, Philosophy of Right, 133. Italics mine.

(c) 2020 Jeffry V. Ocay

https://www.kritike.org/journal/issue 27/ocay december2020.pdf

ISSN 1908-7330
}

(c) BY-NC-ND 
the paramount object of human aspiration. It is precisely in the context of this unique Hegelian conception of freedom that many social and political theorists today have sought refuge in Hegel rather than in Kant who champions the idea of individual autonomy. As Steven Smith writes, "If contemporary liberals, such as Rawls, have been led to rediscover Kant, liberalism's critics have been forced to reinvent Hegel." 37

The Graduate School, Eastern Visayas State University Tacloban City, Philippines

\section{References}

Bloom, Allan, The Closing of the American Mind (New York: Simon \& Schuster, 1987).

Cortella, Lucio, The Ethics of Democracy: A Contemporary Reading of Hegel's Philosophy of Right, trans. by Giacomo Donis, (New York: SUNY Press, 2015).

Deranty, Jean-Philippe, Beyond Communication: A Critical Study of Axel Honneth's Social Philosophy (Leiden: E.J. Brill, 2009).

Deranty, Jean-Philippe and Emmanuel Renault, "Politicizing Honneth's Ethics of Recognition," Thesis Eleven, 88:1 (February 2007).

Franco, Paul, Hegel's Philosophy of Freedom (New Haven and London: Yale University Press, 1999).

Hegel, G. W. F., Philosophy of Right, trans. by S. W. Dyde, (Mineola, New York: Dover Publications, 2005).

Honneth, Axel, Freedom's Right: The Social Foundations of Democratic Life, trans. by Joseph Ganahl, (New York: Columbia University Press, 2014).

The Pathologies of Individual Freedom: Hegel's Social Theory, trans. by Ladislaus Löb (Princeton and Oxford: Princeton University Press, 2010).

Kierans, Kenneth, "The Concept of Ethical Life in Hegel's Philosophy of Right," in History of Political Thought, 12:3 (Autumn 1992).

Luther, Timothy C., Hegel's Critique of Modernity: Reconciling Freedom and Community, (United Kingdom: Lexington Books, 2009).

Lysaker, Odin, "Institutional Agonism: Axel Honneth's Radical Democracy," in Critical Horizons, 18:1 (February 2017), 33-51.

Marcuse, Herbert, Hegel's Ontology and the Theory of Historicity, trans. by Seyla Benhabib, (Massachusetts: The MIT Press, 1987).

${ }^{37}$ Smith, Hegel's Critique of Liberalism," 4. Italics mine.

(c) 2020 Jeffry V. Ocay

https://www.kritike.org/journal/issue 27/ocay december2020.pdf

ISSN 1908-7330

(c) BY-NC-ND 
Ocay, Jeffry, "Hegel Reframed: Marcuse on the Dialectic of Social Transformation," in Philosophia: International Journal of Philosophy, 16:1 (January 2015).

"Heidegger, Hegel, Marx: Marcuse and the Theory of Historicity," in Kritike: An Online Journal of Philosophy, 2:2 (December 2008).

"Ethics of Refusal: Globalization and the Penan People's Struggle for Recognition," in Budhi: A Journal of Ideas and Culture, 19:2\&3 (2015).

"Eroticizing Marx, Revolutionizing Freud: Marcuse's Psychoanalytic Turn," in Kritike: An Online Journal of Philosophy, 3:1 (June 2009).

Patten, Allen, Hegel's Idea of Freedom, (Oxford: Oxford University Press, 2005).

Pippin, Robert B., "What is the Question for which Hegel's Theory of Recognition is the Answer?," in European Journal of Philosophy, 8:2 (2000)..

Rae, Gavin, "Realizing Freedom: Hegel and Ethical Life," in Realizing Freedom: Hegel, Sartre, and the Alienation of Human Being (London: Palgrave Macmillan, 2011), 183-230.

Schroyer, Trent, The Critique of Domination: The Origins and Development of Critical Theory (Boston: Beacon Press, 1973).

Smith, Steven B., Hegel's Critique of Liberalism: Rights in Context (Chicago and London: The University of Chicago Press, 1989).

Stratton, W. G., "The Problem of Democracy in Hegel's Philosophy of Law," in Archives for Philosophy of Law and Social Philosophy, 74:1 (1998).

Tunick, Mark, "Hegel's Claim about Democracy and his Philosophy of History," in Hegel and History, (New York: SUNY Press, 2009).

Verene, Donald Philip, Hegel's Absolute: An Introduction to Reading the Phenomenology of Spirit, (New York: State University of New York Press, 2007).

Williams, Robert R., Recognition: Fichte and Hegel on the Other, (Albany: SUNY Press, 1992).

Translator's Introduction to Georg Wilhelm Friedrich Hegel, Lectures on the Philosophy of Spirit, 1827-8, trans. by Robert R. Williams (New York: Oxford University Press, 2007).

Wood, Allan W., Hegel's Ethical Thought, (New York: Cambridge University Press, 1990).

Žižek, Slavoj, "The Violence of Liberal Democracy," Assemblage, Vol. 20 (April 1993), 92-93.

Less Than Nothing: Hegel and the Shadow of Dialectical Materialism, (London: Verso, 2012). 